\title{
Sociology of Everyday Life with Uncertainty and Differences during the Covid-19 Pandemic Process: The Case of Turkey Retirees Association
}

\author{
Ahmet Kosar ${ }^{1}$, Aytul Kasapoglu² \\ ${ }^{1}$ Institute of Social Sciences, Baskent University, Ankara, Turkey \\ ${ }^{2}$ Department of Sociology, Baskent University, Ankara, Turkey \\ Email: makasapoglu@baskent.edu.tr, ahmettkossar@gmail.com
}

How to cite this paper: Kosar, A., \& Kasapoglu, A. (2021). Sociology of Everyday Life with Uncertainty and Differences during the Covid-19 Pandemic Process: The Case of Turkey Retirees Association. Advances in Applied Sociology, 11, 747-772.

https://doi.org/10.4236/aasoci.2021.1112061

Received: November 19, 2021

Accepted: December 28, 2021

Published: December 31, 2021

Copyright $\odot 2021$ by author(s) and Scientific Research Publishing Inc. This work is licensed under the Creative Commons Attribution-NonCommercial International License (CC BY-NC 4.0). http://creativecommons.org/licenses/by-nc/4.0/ (c) (i) (8) Open Access

\begin{abstract}
The measures taken immediately after the declaration of Covid-19 as a Pandemic, especially the elderly, those with chronic diseases, women, children and the disabled were most affected. The primary aim of this article is to reveal the difficulties and uncertainties experienced by retirees over the age of 65 , and the tactics and strategies of coping with them in daily life, with a relational and reflexive sociological perspective during the 2020-2021 Pandemic process. In accordance with the mixed design principles in the research, both in-depth interviews (qualitative research) and questionnaires (quantitative research) were conducted with participants over the age of 65 who are members of the Ankara Branch of the Turkey Retirees Association. In accordance with the grounded theory methodology applied in the qualitative part of the research, after the social, economic and psychological problems of the elderly were revealed in detail with open and axial coding, the core concept of solidarity was reached. Finally, the life story of the retirees was written using the tree metaphor. Findings supported by quantitative data are discussed with the relational sociological literature on the basis of uncertainty and differences, and how the elderly people hold on to life with the strategies and tactics they apply is revealed.
\end{abstract}

\section{Keywords}

Relational Sociology, Mixed Design, Grounded Theory, Everyday Life, Retirees, Solidarity, Covid-19 Pandemic 


\section{Introduction}

Most of the natural problems experienced are social in terms of their consequences. For example, although an earthquake is actually a natural event, it is social in terms of its consequences. Because, by establishing heavy industry on loose agricultural lands, causing the settlement of the crowded population and losing many lives when an earthquake occurs, in Giddens' (1990) terminology, it is a man-made disaster, not a natural disaster. Even though the depletion of the ozone layer is seen as a natural phenomenon, it is the consumption culture of the industrial society that leads to it (Giddens, 1994; Beck, 1992). Likewise, the emergence of a virus seems to concern biology at first glance. The spread of this virus and finally reaching a point that affects and even determines people's lives at the level to be declared a Pandemic is a social problem in terms of its social effects.

The pandemic has not only caused psychological anxiety and depression at the individual level, many people have lost their jobs, spouses, relatives, economies have shrunk, production has slowed down, healthcare institutions have collapsed, multi-layered social inequalities have tended to increase, human rights violations and violence have become widespread (Aykan, \& Bilginer, 2021; Aydin, 2021). As Agamben (1998) states, exceptions have become ordinary.

The American social scientist Mills (1959), who was outcast for criticizing American society during his lifetime, said that it is a moral duty to have sociological imagination. Even beyond social scientists, he stated that people, in general, should understand their personal concerns in a broader social context, for example, by relating them to the dominant human types and economic systems of their time. Indeed, the current Covid-19 pandemic has shown us that all emerging and ongoing problems are in fact shaped by wider social and historical conditions and problems of everyday life. As a matter of fact, developed Northern European countries with some smaller populations, well-managed and high health expenditures were less affected by the Pandemic (Coccia, 2022). In addition, there are some studies showing that increasing digitalization during the pandemic period causes human rights violations as well as benefits. For example, increasing threats to privacy and confidentiality may result in discrimination and violence. Before the Covid 19 Pandemic, such problems were especially experienced in AIDS disease, which is also transmitted by a virus (Davis, et al., 2020). In fact, comparative studies have been made between Covid-19 and HIV/AIDS (Özen, 2021).

In the Covid-19 epidemic, digital inequalities gained importance in addition to the problems that individuals over the age of 65 face in various areas of their daily lives, such as health, economics, socialization and shopping. In addition, as a result of various restrictions introduced, older adults have become more socially isolated and their loneliness has increased.

According to "Social Isolation and Loneliness in Older Adults: Review and Commentary of a National Academies Report" (Donovan \& Blazer, 2020), social 
communication of elderly individuals with family and friends is restricted with stay-at-home practices. Although the practice of social isolation seems to be a life-saving function, it also deprived individuals of communication, which is a basic human need. Accordingly, low social support negatively affects the general health of the elderly is among the most important findings of the report (Donovan \& Blazer, 2020).

Although Turkey is classified as a young population in European countries in terms of demographics, it has tended to turn into a rapidly aging structure today (TUIK, 2021). In this context, the negative effects of the policies applied to the elderly population during the Covid 19 pandemic process (Şentürk, 2021), the aging process and the issue of daily life have become even more important. Because the historical events that develop in the life periods of the individuals, the changing living conditions, can directly affect the aging process as the sensitive period of the individual. In fact, it should not be forgotten that according to the Cumulative Advantage/Disadvantage Theory, which was put forward by Price and Merton in the 1960s and developed by Dannefer (2003), inequalities in the individual become more evident in the aging process. It is undeniable that the advantages and disadvantages experienced in middle adulthood have a direct effect on determining general well-being, especially economic and health conditions in old age.

\subsection{Theoretical Framework}

This study was conducted in accordance with relational sociological principles. One of its most basic features is that it considers aging as a process in daily life and rejects dualism and essentialism. Italian relational sociologist Pierpaolo Donati (2011) states that in aging studies, intergenerational relations and generativity (Rossi et al., 2014) affect both identity, happiness and well-being. From a relational point of view, we can say that the aging process is also a social relationship, since it is accepted that every social phenomenon actually consists of social relations. Claiming that the relational view is a paradigmatic transformation, Donati $(2011,2015)$ sees this process as AGIL, drawing on the systems theorist T. Parsons (1960). Here, there are four subsystems as A (adaptation), G (Goal attaintment), I (Integraion), L (Latency). In fact, Donati, slightly different from Parsons, with A; resources and obstacles; $G$ indicates the goals, $G$ indicates the rules, and $\mathrm{L}$ indicates the values. However, just like Parsons, he accepts that these subsystems or poles are interrelated in every social phenomenon. According to Donati (2015), there is an aging process in every society and family, which consists of the movement of these poles called AGIL. Because it is often inevitable for people to consider both their own tendencies and needs and the reactions of other people with whom they interact.

According to Meda et al. (2017), when there is intergenerational solidarity, both adults/parents and children take care of each other's needs. On the other hand, there are two different worlds in which the old do not think about the young and the young do not think about the old, and there is a conflict between 
them. The first of these is called the Family/intergenerational solidarity index, and the second is called the pro-intergenerational orientation index. These two dimensions are important as the subjective nature of each individual's aging process. These analytical components have been used in many studies in recent years (Meda et al., 2017; Bramanti \& Meda, 2016).

Some indexes are also used in relational sociological aging studies on physical activity, personal and relational satisfaction and anxiety. For example, Meda et al. (2017) also looked at physical activities such as walking, soccer, golf, and gardening. In the context of the life satisfaction index, income, health and housing gain importance. In terms of relational happiness, family, friendship and neighborhood ties are considered. In terms of trust and concerns, health problems, economic problems, hospitalization and who will be cared for are included in the index. The last index is about the support given or received. Bureaucratic procedures such as paying taxes and bills, and small economic contributions to grandchildren, spouses and friends are among these. Health, education, cultural and religious activities, donations to the poor, human and environmental rights activities are included in the index of those reached through association, that is, with a more formal structure. Finally, the skills of using communication technologies are included in the mobile phone, PC, and internet search index. In fact, all these are indexes that reveal the status of people. As well as age, gender, education and occupation, the level of health of individuals, the number of friends, relatives and neighbors are also more important than the income they have. All mentioned factors have been discussed in our research as indicators of a process-based, holistic view.

On the other hand, the sociology of everyday life (Lefebvre 1971; de Certeau 1984) occupies a central place in the theoretical framework of this study. The most famous person concerned about the resistance of ordinary people, old or poor, to the rules set by the powerful or public authority in daily life, is the French sociologist de Certeau (1984). He draws our attention to the importance of the practice of those who have become powerless. Because these practices show us the resistance of the weak against the suppression strategies applied to them in daily life. According to de Certeau (1984), strategies are very different from tactics. Strategies are actually hegemonic structures that extend to the whole of daily life and set limits. Therefore, strategies also include disciplinary mechanisms in certain power areas. Strategies can set new rules for new arrangements in the hegemonic structure. However, tactics, very different from strategies, are resistance techniques developed by the weak to erode the power that sets the rules in question or even leak. These tactics are often developed temporarily and are not permanent. Tactics do not have a specific place. Most of the time they are just looking for a suitable leaking opportunity. For example, an elderly couple may want to do their shopping or transactions at the bank when they go to the doctor. This tactical development and application is a kind of intellectual synthesis. In fact, these tactics are used by workers, immigrants, ethnic minorities and due to our subject, it is possible to apply it by very different weak 
groups such as the elderly. For example, de Certeau (1984) describes the tactics of Native Americans, although they did not have the power to challenge. The most important feature of these tactics is that ordinary people resist the pressure applied to them (cited in Kasapoglu, 2015; 2019).

On the other hand, with the Covid-19 process we are in, there are various transformations and uncertainties at individual and social levels. According to some experts working on uncertainties, existing uncertainties at a certain level are the main factor in the emergence and increase of social interactions (Melamed \& Savage 2013; Moscovici et al., 1969; Pfeffer et al., 1976; Tushman \& Romanelli, 1983). In addition, people tend to seek various pursuits during the uncertainty process, and at this point, they benefit from social interaction in order to reduce uncertainties (Melamed et al., 2019).

As important representatives of relational sociology, the conceptualization and classification of uncertainties by $\mathrm{H}$. White et al. (2013) also contribute to reading the uncertainties we experience in the Covid-19 era. H. White (1992) in his work titled "Identity and Control" claims that people avoid "uncertainty" situations that occur in their lives and try to control these uncertainties. He thinks the existing concepts inadequate and prefers the concept of "identities" that play a critical role in social interaction. In short, new identities arise in the face of difficulties in social life, due to the search for safety in situations of uncertainty. It is undoubtedly an expected situation for individuals to try to construct a new identity by feeling the need to control certain uncertainties.

White et al. (2013) focus on three basic concepts while examining these uncertainties. They are classified as "ambage", "ambiguity" and "contingency" respectively. Ambage is the uncertainty in social relationships, while ambiguity is cultural uncertainty in meanings and values. Finally, the third type of uncertainty, contingency, emerges as an uncertainty situation that comes from the outside and affects the system. In addition, another concept in terms of our subject is "turning points". Because, according to the increase and decrease in the various types of uncertainty mentioned, "turning points" that allow identities to develop strategies emerge (White et al., 2013: pp. 138-139).

\subsection{Research Design}

Populations and societies graying out with aging is one of the important demographic situations of the 21 st century. In short, this means an increase in the proportion of the elderly in the general population. In connection with this situation, it is an expected phenomenon that the proportions of children and active workers in the society will decrease in the process. Duben (2018) underlines that the proportion of the elderly has increased in many countries in the world since 1950. According to some statistical calculations, it is predicted that the rate of the total elderly population in the world will be $16 \%$ in 2050. In Europe, which is

called the elderly societies, this rate will reach $30 \%$. In parallel with this, the rate of the elderly in Turkey, which is considered young, will reach 18\% (Duben, 
2018).

Turkey is actually in the process of demographic transformation. In addition to the improvement in nutrition and access to clean water and hygiene conditions, the expected life expectancy has been extended with the decrease in fertility and mortality rates, and developments in the fields of medicine and technology. As a result, the age structure of the population has entered a trend of change. As a matter of fact, according to official state data (TUIK, 2021), the elderly population has increased by $22 \%$ in the last 5 years. It has been shown in the projections that the ratio of the elderly population to the total population will be $10 \%$ in the 100 th founding year of the Republic, that is, in 2023 (https://data.tuik.gov.tr/Bulten/Index?p=Istatistiklere-Yaslilar-2019-33712, 2019). In Turkey, it is seen in the population pyramids where the population is getting older. However, the dramatic thing is that we age by impoverishing.

Research problem: According to the definition of the United Nations (UN), if the proportion of the elderly population in a country is between $8 \%-10 \%$ of the total population, the population of that country is old. If it is over $10 \%$, it means that it is very old. According to the "TUIK Report of Change of Elderly Population" (2021) published by the Ministry of Family, Labor and Social Services, there are a total of 24 million 940 households in Turkey. Of these, over 5.5 million households have at least one person aged 65 and over. This is also an indication that at least one fourth of the households have an elderly person. According to the same report, the number of elderly people living alone has reached 1 million 373 thousand 521. Among the elderly living alone, the rate of women is higher $(75.7 \%)$. This rate is lower in men $(24.3 \%)$. It is possible to comment on these data that women have a higher life expectancy, as well as that men live with their children or remarry instead of living alone.

In the time period from March 2020, when the Covid-19 epidemic, which first appeared in China in November 2019 and was declared a Pandemic by the World Health Organization, to this day, various changes have occurred in daily life in Turkey as well as in all parts of the world. out. This process, which we were caught unprepared for, has radically changed our routines by directly threatening the vital well-being of people. Moreover, there are many uncertainties regarding the upcoming process.

As a field that has gained great importance in sociology, our daily life (Lefebvre, 1971; de Certeau, 1984) has been in a period of regression with the vaccine found as a result of scientific studies, although it has been highly affected by Covid-19. In this period, the use of space, house works, socialization processes inside or outside the home of those who retired after working intensively in their youth gain importance. However, while adults who are not passive recipients try to cope with the practices brought by public authorities or sovereigns during the Covid-19 process, how they transform the imposed restrictions and new rules for their own interests gains more importance. It is a well-known fact that the elderly, who have fallen into "subaltern" (Gramsci, 1992) status, continue their 
lives by leaking through cracks and developing some tactics and strategies (de Certeau, 1984; Kosar \& Kasapoglu, 2021).

The main problem of this research is that after the declaration of Covid-19 as a Pandemic, the daily lives of the population aged 65 and over, which is one of the most affected, have multi-layered (social, economic, psychological, cultural) deep inequalities.

Importance and limitations: Today, one of the most important factors determining the living conditions and experiences of the population aged 65 and over is the labeling or marginalization of people by classifying them in a specific "elderly" category. This situation can actually lead to the stereotyping of a certain population group. Therefore, it can also lead to ignoring the "unique" and "different" problems that people experience. Therefore, this study gains importance in terms of showing that the reactions shown are as different as the problems experienced by people during the Covid-19 process.

Although there are some studies that qualitatively investigate the fact that the elderly go to retirement associations to relieve their loneliness and thus live in solidarity by using their social capital (Kurtkapan, 2019), it can be said that the fact that our study was conducted as a mixed design with a much larger sample increases its importance.

The most important limitation of this study is the adequate face-to-face interviews under pandemic conditions. In phone calls, the inability to focus with the desire of adults to talk about other subjects is a sensitive situation that is frequently observed, but is easily resolved after gaining a certain experience by the researchers.

Objectives: The primary aim of this research is to reveal the difficulties experienced by individuals who retired after working throughout their lives and how they hold on to life from various perspectives. Everyday life is a concept that is related to all human activities and that deals with differences and conflicts together. When we say everyday life, all the interactions in society that make people human are included. Therefore, in this study conducted on daily life, all daily activities of retirees were discussed by associating them with each other.

In this article, answers to the following questions were sought as sub-problems. In other words, the opinions of the members of the Turkey Retirees Association in Ankara, as a nationwide organization, on the following questions were investigated:

1) What are the strategies of the participants to cope with the feelings of loneliness they experience during the Covid-19 process?

2) How do the participants meet their daily needs (shopping and housework) during the Covid-19 process?

3) What is the frequency of meeting with neighbors, friends, relatives within the scope of Covid-19 measures?

4) What are the changes in the economic conditions of the participants during the Covid-19 period and how do they struggle with these changes? 


\subsection{Methodology}

In the study, the mixed design method, in which qualitative and quantitative researches are carried out together, was applied (Creswell \& Clark, 2011). There are three models of the mixed pattern research method, one of these three models, the exploratory mixed methods design, was preferred. In the exploratory sequential mixed method approach, it starts with qualitative studies and continues with quantitative research. In this method, the researcher discovers the phenomenon through qualitative research, and in the next stage uses the data obtained in the quantitative research dimension (Creswell \& Clark, 2011). In the qualitative research part of the study, "grounded theory methodology" was used. This approach has been used in various studies as it is similar to relational sociology, which examines interactions as a process (Kosar \& Kasapoğlu, 2021; Isik \& Kasapoğlu, 2021). In mixed-method studies (see Figure 1), analyzes can be presented in various formats after both data sets are obtained. In this study, the result was reported after the qualitative and quantitative data were woven together like weaving (Creswell \& Clark, 2011).

Grounded theory methodology is based on a tradition of qualitative research that uses certain systematic procedures established to develop theory about a phenomenon. First used by Glaser \& Strauss (1967), this method looks critically at understanding and explaining social reality through existing theories. According to Glaser, \& Strauss (1967), grounded theory methodology, which is a systematic analysis technique, is needed to gain new perspectives. While trying to develop a theory about the process and action, what is wanted to be explained with the theory or concepts reached is actually the explanation and interpretation of the facts (Creswell, 2013: p. 85).

The basic data collection technique in the grounded theory approach is the interview. Because interviews are dynamic. The researcher is constantly oscillating between the theory he/she is developing and the data he/she has obtained from individuals. It is aimed to fill in the gaps, if any, by constantly conducting new interviews. In addition, the "principle of openness" is important in grounded theory studies. In this theory, information gathering and analysis are simultaneous processes (Kasapoğlu, 2015: p. 23).

After selecting a category at the center of the theory to be developed, the synthesis of the categories (axial coding) is done. In selective coding, there is a concentration on a central (core) category selection. Now the analysis and decoding process are integrated and correlated during selective coding. Finally, a descriptive story is created in order to facilitate the reader, together with the key concepts that explain the phenomenon and introduce the theoretical framework, together with the basic categories determined in the integration stage (Corbin \& Strauss, 1990). The main reason for using grounded theory in the study is that it is in harmony with relational sociology, which cares about process analysis and self-reflexivity. 


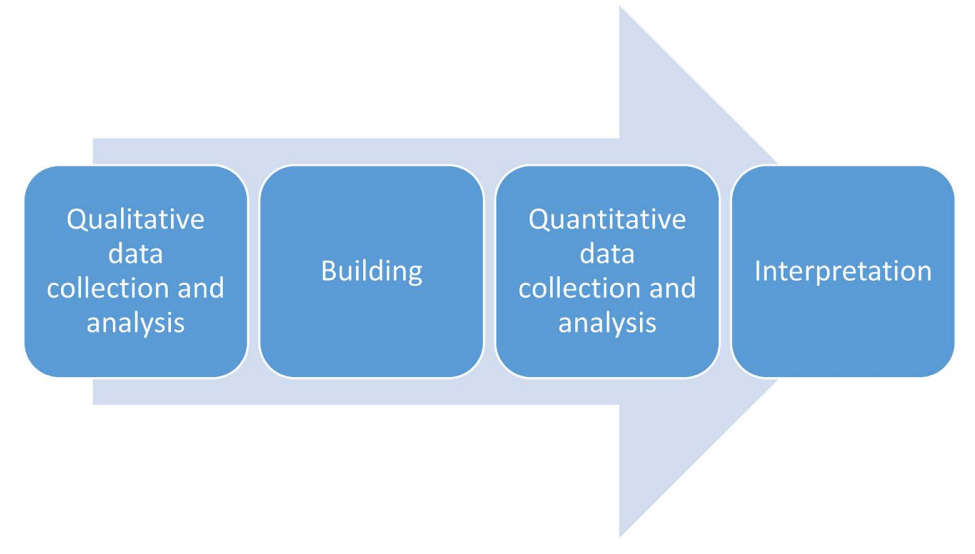

Figure 1. Exploratory sequential mixed design (Creswell \& Clark, 2011).

Appointments were made for the study to be able to conduct interviews with the members of Türkey Retiree Association in Ankara. In the interviews held between January 2021 and March 2021, open coding, axial coding and selective coding stages, which are the stages required by grounded theory, were applied. Various questions were asked to the participants in the sample to determine the changes in the feelings and thoughts of the individuals during the period from the beginning of the restrictions to this day. In the quantitative part of the study, a questionnaire was applied. Within the scope of the survey, a total of 32 questions, including the scale, were asked to the members of the Ankara Turkey Retirees Association aged 65 and over. The questionnaire included questions measuring the demographic information, education and economic status of retired individuals.

Universe and Sample: In accordance with the qualitative research purpose of the study, 16 retirees who were selected in accordance with the "theoretical sampling" technique were interviewed. Since the findings obtained in grounded theory studies are limited to the participants interviewed, there is not a wide universe in which the findings can be generalized.

In the quantitative part of the study, the members of the Turkey Retirees Association (TUED) Ankara headquarters formed the universe of the research. The sample, on the other hand, consisted of 60 people (government officer, blue-coloured worker and self-employed) who were selected among the members of these branches. Therefore we applied stratifed sampling.

Turkey Retirees Association was established in 1970 and has branches in almost every city of Turkey. The association is a member of the Turkish Pensioners' Platform and the Aging Platform. As an observer member of the European Union Platform for the Elderly (AGE-Europa), the Association represents Turkey in the EU. The association is a non-governmental organization that attracts the attention of all retirees, especially retired workers, widows and orphans.

\section{Findings and Discussion}

In this study, Mixed Design, in which quantitative and qualitative research me- 
thods are planned simultaneously, was used. Such a strategy was followed in the research in order to better show the differences and thus the changes in the daily lives of the retirees due to the Covid-19 Pandemic.

On the basis of Open Coding, qualitative and quantitative data were presented in parallel with the research objectives, starting with loneliness, which is one of the most important problems experienced by the participants.

1) Methods of Coping with the Feeling of Loneliness in the Covid-19

\section{Process}

It can be said that among the retired participants, who generally feel lonely, they mostly feel better when they find activities such as painting and puzzles, watch TV, make phone calls, read books or spend time with their spouse and children. Along with all this, they also said that they did not lose their hope, although there were some who stated that their lives had become unpleasant and that they were on the verge of depression. In addition, in the answers given, it was stated that being in the same city with close relatives and children contributes to the general well-being of the people at the point of coping with the troublesome processes. Because many participants stated that they do not feel lonely because they live in the same city with their children and relatives.

P4: "There were moments when we felt lonely, but we went through this process with my wife. We get rid of these feelings by reading books together, sharing what we have read and various cultural activities." (Retired Civil Servant, 70 years old Male)

P6: "Since my children and close relatives were with me, I almost never felt lonely." (Băg-Kur Retired, 65 years old Male) (K1, P2, K3, K11, K12)

P7: "We reduced the feelings of loneliness a little bit by watching TV and making phone calls." (Retired Worker, 65 years old Male) (F5, F7)

P9: "Voice and video phone calls relieved me." (Retired Civil Servant, 65 years old Female)

P10: "I didn't feel very lonely. Because I spent a lot of time on the Internet. I was able to see my children in the same city." (Bağ-Kur Retired, 67 years old Female)

When we look at the distribution percentages of the methods of coping with the negative emotions they experienced during the post-Covid-19 restrictions, it was revealed that the majority of the participants coped with the feelings of loneliness by 71.7\% "Watching TV" and 66.7\% "Speaking on the Phone with Friends and Relatives" (see Table 1).

These data can also show the needs of retirees such as internet, computer literacy, smart phone use, which are helpful functions in diversifying their leisure activities. At the highest rates, it is seen that people cope with feelings of loneliness by watching television.

At this point, we can see that smartphone and internet ownership are more critical in coping with the feelings of loneliness of retirees. Because opportunities such as internet and smart phone ownership are opportunities that allow people 
Table 1. Distribution of methods for overcoming negative emotions in the restriction process.

\begin{tabular}{cccccccc}
\hline & \multicolumn{2}{c}{ Yes } & \multicolumn{2}{c}{ No } & \multicolumn{3}{c}{ Total } \\
\cline { 2 - 8 } & $\mathrm{N}$ & $\%$ & $\mathrm{~N}$ & $\%$ & $\mathrm{~N}$ & $\%$ \\
\hline By Acquiring New Hobbies & 9 & 15.0 & 51 & 85.0 & 60 & 100 \\
By Contacting Friends and Relatives & 40 & 66.7 & 20 & 33.3 & 60 & 100 \\
By Watching television & 43 & 71.7 & 17 & 28.3 & 60 & 100 \\
By Praying & 13 & 21.7 & 47 & 78.3 & 60 & 100 \\
By Reading & 29 & 48.3 & 31 & 51.7 & 6 & 100 \\
\hline
\end{tabular}

to realize their own wishes and give them a space of freedom. As a matter of fact, Özsungur (2018), who examined the effect of technology acceptance and use behaviors on successful aging, stated that the negative effects of physical, psychological and social losses that may occur in old age can be reduced by internet use. In addition, it has been observed that there has been an increase in the internet usage rates of people aged 65 - 74 during the Covid-19 Pandemic process (https://www.aa.com.tr/tr/science-technology/kovid-19-salgini-surecinde-yaslila r-internet-hugged-distances-hanged-with technology/2182534).

\section{2) Meeting Shopping Needs}

Retirees stated that they generally meet their shopping needs through their children, apartment doorkeepers, close relatives and the internet. However, those who can use the internet are few in number, and the participants who have a market nearby were also able to do their shopping on their own during the time off (see Figure 2).

$\mathrm{P} 1$ "My children and relatives usually help me with my shopping needs, we rarely get help from the doorkeeper." (Retired Civil Servant, 77 years old Male) (P3, P11, P12)

$\mathrm{P} 2$ "My nephews helped me with this type of needs and showed the necessary attention. They also supported me as much as they could in meeting my shopping needs." (Retired Worker, 71 years old Male)

P8: "I can order my shopping online. There is a market near us once in a while, and I can do my own shopping there." (Retired Civil Servant, 65 years old Female) (P9, P10)

\section{3) Meeting their needs at home (dishwashing, laundry, food, etc.)}

When the participants were asked whether they received paid help from outside in matters such as washing, dishwashing, cleaning, cooking, and how they met their domestic needs, the majority of the answers were "We meet with my spouse by helping each other". However, some participants stated that before the pandemic, they received their regular assistants once every two weeks after the epidemic was seen in our country. It has been revealed that the majority of the people who received paid assistants from outside before the pandemic were retired civil servants. This situation shows that, together with the economic difficulties, this group also saves on getting help in housework (see Figure 3). 


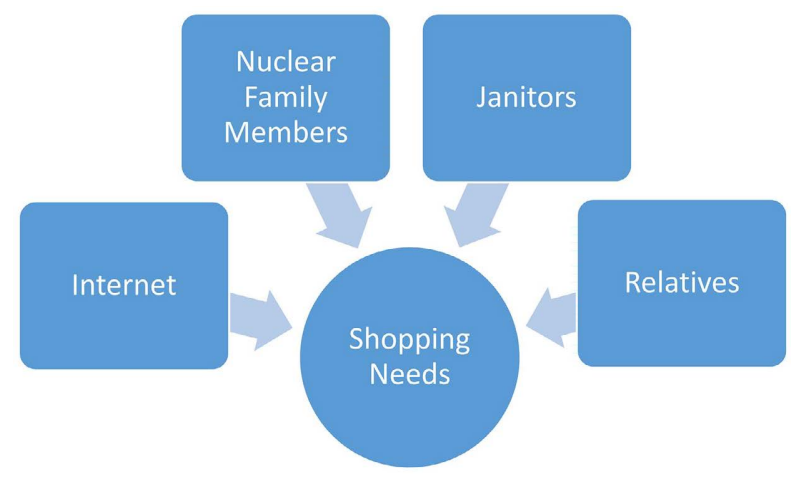

Figure 2. Meeting shopping needs.

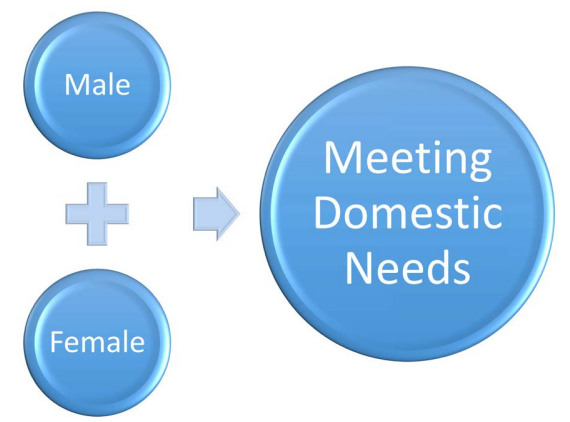

Figure 3. Meeting domestic needs.

P1: "We recruit a female assistant every 15 days." (Retired Civil Servant, 77 years old Male)

P5: "I always get help." (Retired Civil Servant, 76 years old Female)

P2: "By helping out with my spouse" (Retired Worker, 71 years old Male) (P3, P4, P7, P8, P14, P11, P15)

With the support of the United Nations Development Program (UNDP), the research examining the changes in the gender-based division of labor in the Covid 19 crisis in Turkey shows that the unpaid workload for women has increased fourfold during the stay-at-home period. In addition, it has been determined that the time spent by men for unpaid domestic work has increased significantly (Ilkkaracan, Memiş and Konda: 2020

https://www.stgm.org.tr/undp-raporu-pandemide-kadinlar-men-4-kati-ucretsizmade). This situation also shows that spouses start to help each other in domestic affairs. According to the survey data results, the majority of the participants marked the option "We do housework by helping out with my spouse" at the rate of $45 \%$. Some $38.8 \%$ stated that they "do their housework without needing help" (See Table 2).

\section{4) Places Traveled in Daily Life}

Participants stated that before the pandemic, they generally visited open spaces, parks, gardens, cafes and neighborhood markets. In particular, there were those who stated that they met with their friends at the retirees' association and visited their relatives. As a result, we can talk about the existence of an active social life for retirees before the Pandemic. There has been a serious decrease in the 
Table 2. Distribution of meeting house chore needs (dishwashing, laundry, cleaning, food).

\begin{tabular}{ccc}
\hline & $\mathrm{N}$ & $\%$ \\
\hline I met these needs with my spouse & 27 & 45.0 \\
I didn't need a cleaner & 23 & 38.0 \\
I received support from a paid cleaner every 15 days & 5 & 8.3 \\
I received support from my children and my relatives & 5 & 8.3 \\
Total & 60 & 100 \\
\hline
\end{tabular}

number of retirees who come to the association 3 - 4 days a week with the Pandemic, and even as a result of the closure of the association at certain intervals, there has been a transition to a home-centered daily life (see Figure 4).

P1: "In normal times, I used to go to the association in Kizılay 4 days a week, I was socializing with my friends here. However, due to the coronavirus, I do not go to such closed places for months as much as possible, I am protected. When the restrictions are lifted, there is a walking area near our house and I go there." (Retired Civil Servant, 77 years old Male)

P2: "In today's conditions, we have to be very careful about such matters. That's why I've been indoors at a minimum level, I keep in touch by talking on the phone, I walk in green areas during off hours." (Retired Worker, 71 years old Male)

P5: "I go to the gardens and parks near us, I love to walk. Also, I used to travel a lot in Ankara, I used to go to neighborhood markets and museums, now I am not going anywhere." (Retired Civil Servant, 76 years old Female)

P8: "He always goes out before Corona; I used to visit relatives and friends. I can't do it anymore, but my wife and I take a walk in the park near our house." (Retired Civil Servant, 65 years old Female) (P6, F9)

P11: "Before the pandemic, we would meet with our friends at home or outside, two or three times a week, and go to outdoor cafes such as tea houses." (Bağ-Kur Retired 66 years old Female) (P10)

P12: "In normal times, I would often go to the parks where I could take a walk, now I do not go out unless I have to, I take care of my routine needs and return to my home." (Băg-Kur Retired, 65 years old Female

One of the social tendencies in the conditions of the pandemic is the people's return to nature. According to Tuna (2021: pp. 338-339), the main reason for this is that people's limited relationship with nature has come to the point of complete rupture with the Pandemic. For this reason, "the rediscovery of nature" (Tuna, 2012) by people has come to the fore. Looking at the statements of the retirees, it was noted that when the restrictions were lifted, they first went to parks and natural green areas. This situation can show the importance of green and open spaces for people in the Covid-19 process. Xie et al. (2020) stated in their study that during the pandemic and the restrictions that came with it, the open parks in the city helped people to socialize and relieved people physically and mentally. According to TPL Special Report (2020); Parks have emerged as safe areas as closed areas have been out of use during the restriction period. 


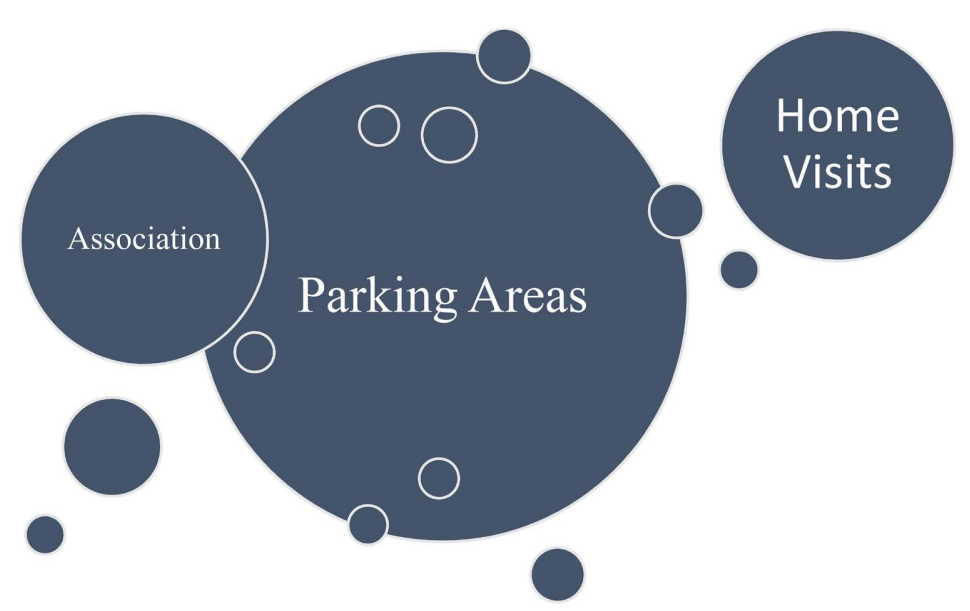

Figure 4. The places they go to in their daily lives.

\section{5) Changes in Social Relations within the Scope of Covid-19 Measures}

During the Covid-19 epidemic, the people in the sample stated that face-to-face communication was mostly over and they only met with members of the family. All of the participants stated that they communicate with and without video over the phone. At this point, we can say that the forms of socialization are mostly realized through phone calls. A few people stated that they attended meetings and held meetings with their relatives via Zoom and Skype applications on the computer.

P3: "We are making more calls by making video calls, we have not been to anyone for months, no one has come to us." (Retired Civil Servant, 70 years old Male) (P6, F8)

P4: "We meet our emotional and social needs by making phone calls. In my business life, I also attend meetings via Zoom or Skype." (Retired Civil Servant, 70 years old Male)

P9: "Phone calls have become more frequent, our face-to-face conversations have decreased to almost zero." (Retired Civil Servant, 65 years old Female)) (P1)

P10: "I don't meet anyone face to face. I only have a dialogue with my nuclear family at home. I can say that my phone calls have increased even more during this period." (Bağ-Kur Retired, 67 years old Female) (P5, P7)

As a result of the interviews, although there are geographical or spatial distances between family members and problems in social relations due to these distances, we can deduce from the data that video/unvideo phone calls, various applications (Skype, Zoom) and the internet help to overcome the mandatory distances brought by the process.

Looking at the survey data, during the Covid-19 outbreak, $66.7 \%$ of the participants marked the "Phone Call with Friends and Relatives" option. This may indicate that face-to-face relations in social relations have decreased. In addition, when we look at the comparisons about Pre- and Post-Covid-19 Solidarity, we can see that the average values of intra-family solidarity increased slightly after 
Covid-19. In solidarity with relatives, there was a significant difference when looking at the value before and after Covid-19. As a matter of fact, when we look at the average values in the table, solidarity with relatives decreased after Covid-19, and this decrease is statistically significant. We can interpret the decrease in solidarity among relatives as the relatives have their own needs or cannot support each other due to the fear of contagion or transmission of the virüs (see, Table 3).

When looking at solidarity with neighbors, there is a statistically significant difference. We can read from the table that the neighbor solidarity averages were high before the pandemic, and that these averages decreased with the pandemic. The main reason for this situation may be the decrease in solidarity as a reflection of the awareness that everyone can be a potential virus carrier and the awareness of being "distance" from people. It can be said that people living in apartments pay more attention in elevators and common areas and stay away from each other due to the fear of disease contamination. We cannot talk about a significant relationship in terms of solidarity with friends. However, when we look at the average values in the table, we can see a decrease in solidarity after Covid-19. Regarding this situation, it can be said that together with the Pandemic, the state of being together socially started to decrease gradually and home-centered daily life reduced solidarity with friends. Also, taking into account the difficulties experienced, it is expected that everyone will be busy with their own needs during the pandemic process.

\section{6) Changes in economic conditions during the Covid-19 Period}

It was stated that together with the pandemic, the pensioners among the participants had difficulties economically, they made careful expenditures, the market prices in general increased a lot, and the pension income and salaries were insufficient in this situation. They stated that they met their needs by getting help from their children and taking loans from banks, especially in their economic difficulties. There are also individuals who state that they do not suffer, but that they cannot save (see Table 4).

P2: "I generally make all my payments with difficulty. Without my children, I cannot live on my pension." (Retired Worker, 71 years old Male) (F11, F15)

P3: "Thank God we did not suffer as a family. But we can't save any money." (Retired Civil Servant, 70 years old Male) (P1)

P4: "Thankfully we do not have any financial problems, I can meet my needs."

P7: "We spend more carefully, we spend according to our budget. We are resisting not to take credit. Because our pensions are insufficient when we consider the living conditions." (Retired Worker, 65 years old Male) (P11)

P12: "We borrowed too much. Our needs and expenses have increased tremendously. We used a bank loan, but we could not even pay the installments." (Bağ-Kur Retired, 65 years old Female)

P13: "My husband and I are both retired. Our children help us to meet some of our needs because market prices and bills put a lot of pressure on our budget." (Retired Civil Servant, 68 years old Female) 
Table 3. Comparative table of subject of solidarity pre-post Covid-19.

\begin{tabular}{|c|c|c|c|c|c|c|}
\hline & $\begin{array}{c}\text { Solidarity } \\
\text { (Pre Covid-19) } \\
\text { Average }\end{array}$ & $\begin{array}{c}\text { Solidarity } \\
\text { (Post Covid-19) } \\
\text { Average }\end{array}$ & $\begin{array}{c}\text { Solidarity } \\
\text { (Pre Covid-19) } \\
\text { Standard Deviation }\end{array}$ & $\begin{array}{c}\text { Solidarity } \\
\text { (Post Covid-19) } \\
\text { Standard Deviation }\end{array}$ & T-Test & $\begin{array}{c}\text { Significance } \\
\text { Level ( } 2 \text { tailed) }\end{array}$ \\
\hline $\begin{array}{l}\text { Solidarity within } \\
\text { the Family }\end{array}$ & 3.8167 & 3.9833 & 1.35911 & 1.25538 & 1.692 & $P>0.96$ \\
\hline $\begin{array}{l}\text { Solidarity with } \\
\text { the Relatives }\end{array}$ & 3.0833 & 2.7167 & 1.46475 & 1.34154 & 2.687 & $P<0.009$ \\
\hline $\begin{array}{l}\text { Solidarity with } \\
\text { the Neighbors }\end{array}$ & 2.6000 & 2.36777 & 1.29143 & 1.28837 & 2.031 & $P<0.047$ \\
\hline $\begin{array}{c}\text { Religious Belief } \\
\text { and Practices }\end{array}$ & 2.2667 & 2.2000 & 1.50555 & 2.2000 & 0.814 & $P>0.419$ \\
\hline $\begin{array}{l}\text { Solidarity with } \\
\text { the Friends }\end{array}$ & 2.9833 & 2.7167 & 1.43198 & 2.7167 & 1.777 & $P>0.81$ \\
\hline
\end{tabular}

Table 4. Distribution of methods to overcome economic difficulties during the Covid-19 pandemic.

\begin{tabular}{ccccccc}
\hline & \multicolumn{2}{c}{ Yes } & \multicolumn{2}{c}{ No } & \multicolumn{2}{c}{ Total } \\
\cline { 2 - 7 } & $\mathrm{N}$ & $\%$ & $\mathrm{~N}$ & $\%$ & $\mathrm{~N}$ & $\%$ \\
\hline I had to borrow money from my relatives & 8 & 13.3 & 52 & 86.7 & 60 & 100 \\
I took a loan from a state bank & 19 & 31.7 & 41 & 68.3 & 60 & 100 \\
I did not borrow any money but I had to reduce my spending & 28 & 46.7 & 32 & 53.3 & 60 & 100 \\
I had no difficulty & 10 & 16.7 & 50 & 83.3 & 60 & 100 \\
\hline
\end{tabular}

Considering the distribution of the methods of coping with economic difficulties during the Covid-19 Pandemic period in quantitative data, $46.7 \%$ of the retirees in the sample marked the option "I Didn't Borrow, But I Had to Reduce My Expenditures". Secondly, 31.7\% marked the option "I took a Loan from State Banks".

As a result, it has been revealed that the retirees participating in the research have difficulties in living on only their pensions. As a matter of fact, in the Turkey Retirement Profile study conducted in cooperation with the Turkey Ritaree Association and Gazi University, it was revealed that $55.6 \%$ of retirees have credit card debts (Arpac1, Cantekin ve Yazıcıoğlu, 2021: p. 71).

In short, it has been determined in qualitative interviews that the financial situation of retired individuals is bad, their loan debts increase and the adult children of pensioners also help with these difficulties. This situation can also show that the family solidarity continues. As a matter of fact, studies on this subject have revealed that "family solidarity" has continued from the past to the present. For example, Alan Duben (2018: p. 73) states that family-oriented elderly care and support is common in every social class in Turkey, family members prefer to live close to each other as they get older, and children support their grandparents in their care.

7) Most Significant Challenges Compared to Pre-Covid-19 
In the interviews, it was stated that the participants opposed the decision to cancel the free bus cards, that the restrictions were long-lasting, and that this situation caused them to become more and lonelier. However, they added that they started to experience difficulties in terms of economy, that they could not have regular health checks, and that they had to constantly seek help from someone else (see Figure 5 and Table 5).

P2: "Loneliness the most, and asking for help from someone else second." (Retired Worker, 71 years old, Male) (P3, F5)

P4: "The most restriction of our freedom, especially the press, does not know the age of 65 because a campaign was organized by the press on the social media, and we were banned from getting on the buses. Secondly, it was one of the points that I regretted that the process was increasingly marginalized." (Retired Civil Servant, 70 years old Male) (P1, P15, P16, P3)

P7: "The most economic difficulties, secondly, I cannot have my health checks regularly." (Retired Worker, 65 years old Male) (K6, P8, P11, P12, P14)

P13: "Our quality of life decreased the most in terms of socialization, secondly, there were disruptions in health services, we had to give up some of our health problems." (Retired Civil Servant, 68-year-old Female)

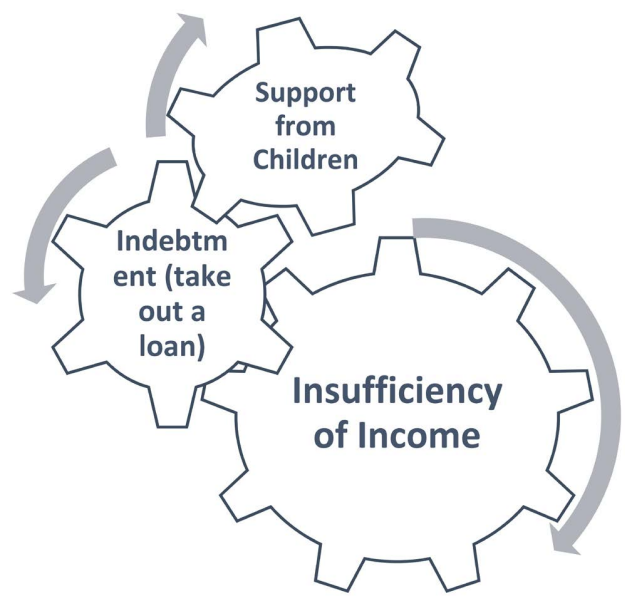

Figure 5. Changes in economic conditions during the Covid-19 period.

Table 5. Distribution of topics that disturbs the retirees most during Covid-19 process.

\begin{tabular}{ccc}
\hline & No & Total \\
\cline { 2 - 3 } & $\mathrm{N}$ & $\%$ \\
\hline Insufficiency of Science (Vaccination Studies) & 5 & 8.3 \\
Loneliness & 7 & 11.7 \\
Uncertainties & 13 & 21.7 \\
Economic Troubles & 28 & 46.7 \\
Failure to Have Regular Health Check-ups & 7 & 11.7 \\
Total & 60 & 100 \\
\hline
\end{tabular}


In the research, many participants saw the decisions taken to prevent the spread of the epidemic within the scope of Covid-19 measures, such as the restrictions imposed on the age of 65 and over, and the cancellation of free public transport cards, as discriminatory treatment (othernization) against them. In addition, we can read people's desire for freedom such as being able to go out, meeting their own needs and walking around in terms of connecting with social life for this age group.

According to the survey data, the first two of the issues that the participants were most disturbed by during the Covid-19 process were "Economic Troubles" with $46.7 \%$ and "Uncertainties" with $21.7 \%$.

\section{Axial Coding}

In axial coding, on the other hand, there is a process of bringing data together in different ways by associating with the categories created in open coding. In other words, the process of associating main categories and subcategories is called axial coding (Strauss \& Corbin, 1990: p. 13).

In terms of identity, while the Covid-19 virus is not an epidemic in Turkey, it is possible for retirees to use different identities such as profession, friend and association identities together in their social lives. With Covid-19, the identities of the "spouses" and "grandparents" of the retirees within the participant came to the fore. For example, the roles of spouses in their homes, the solidarity of spouses with each other, the parent-child relationships they establish with their children... In short, it has been observed that retirees try to hold on to life through these two "identities". In addition, the participants consider the emergence and spread of the Covid-19 virus as "contingency." This situation, in a way, has emerged as a "turning point" in people's lives.

As a result of the deciphers obtained from the interviews, the social relations of the people on the subject of "ambage" were affected from various aspects. These can be listed as family, friend, neighbor, relative and association relations. In addition, it has been revealed that while the intensity of retirees' domestic relations increases during restriction periods, they minimize their social relations outside the home. This situation has led to an uncertainty in the framework of social relations. On the other hand, the participants try to overcome the reductions and uncertainties in social relations in different ways. It has been revealed that they mostly overcome the uncertainties in terms of social relations through phone calls.

On the subject of ambiguity, that is, in values, we can evaluate the opinions of retirees on the meaning and duration of the restrictions imposed on the age of 65 and over during the Covid-19 epidemic, and whether this situation reduces the transmission of the virus, within the framework of "ambiguity".

In the study, various problems such as loneliness, economic difficulties and not being able to socialize as a result of the closure of the 65-year-old and older group to their homes have come to the fore. At the point of overcoming the problems, the participants developed various tactics. The findings revealed that 
the retirees among the participants struggled with the difficulties brought by the process by switching from regular paid assistants to more cooperation with their spouses, receiving material and moral support from their children, and continuing their phone calls. For example, participants with the code P3, P4, P8, P13, P14 stated that while they used to employ regular paid assistants in their homes before the Pandemic, they gave up the helper in the process with the onset of the Pandemic and they met their domestic needs (dishes, laundry, food, cleaning) by helping their spouses. In this respect, we can say that the solidarity between the spouses and the absence of paid assistants or caregivers function as a "tactic" in terms of holding on to life.

The general economic difficulties experienced by the retirees in the sample were such as paying bills and increasing the prices of market needs. It has been seen that they try to find solutions by getting support from their children, taking bank loans and reducing their expenditures. We can also interpret the situation of reducing expenditures and getting support from their children as tactics. For example, participants coded P7 stated that they spent more carefully, while participants coded P1, P2, P11 and P15 stated that they received support from their children. In terms of feelings of loneliness, although there are some who emphasized that many participants do not feel lonely because they live in the same city with their children, they said that they generally meet their socialization needs through phone calls.

In the light of the data obtained, we can see that the participants overcame the difficulties they experienced from various aspects. In terms of social relations, we can interpret from the data that being able to talk with their children face-to-face or on the phone by keeping the distance on weekends and talking to their friends on the phone is psychologically good and reduces their loneliness. It is also stated by them that the ownership of technology (smartphone, internet) provides continuity in the participation of some retirees in social life. For example, participant P10 stated that he did not feel lonely because he could spend a lot of time on the internet, and participant P9 stated that he did not feel lonely by making audio and video phone calls.

As a result, although there is a resistance against uncertainties from basic needs to emotional and social needs of individuals, we can say that the intersection point is "family solidarity" in solving different problems experienced. It has been tried to protect general well-being by reducing general expenses, getting support from their children, helping spouses with each other and maintaining social relations through phone calls.

\section{Selective Coding (Core Concept)}

At this point of the research, it is necessary to start explaining the results obtained from the open and axial coding by determining a core concept. Selective coding is a process in which a central category is determined and other categories are systematically associated with this category and the main core concept is developed among the categories (Strauss \& Corbin, 1990: p. 13). 
The core concept of this study was determined as "solidarity". In the data we obtained in our interviews, it was concluded that sociological and cultural solidarity between generations continues, that is, it is maintained. At this point, we can accept the family institution as the most basic institution where the bio-psycho-social needs of individuals are met in a holistic manner. In today's modern conditions and in the new conditions after Covid-19, it can be said that it is a reflexive relationship network where family solidarity is at the forefront in meeting the various needs of the participants (see Figure 6).

\section{Tree Metaphor and Solidarity}

In a previous study we conducted, the effects of Covid-19 on the elderly and their survival strategies (solidarity) were explained through the metaphor of the "river" (Kosar \& Kasapoğlu, 2021). In this study, the metaphor of the "tree", which is the source of life of nature and the universe, is emphasized. It was thought that many living creatures, in which birds and butterflies fly in green leaves, its branches stretch up to the sky, its roots deepen underground, and around which it grows in the shade of saplings, find peace under this big tree. In this study, our grandparents aged 65 and over are likened to such a tree.

Over time, an insect species has been seen in the forest where this tree is located, spreading and damaging with an unprecedented speed. Experts have determined that this insect is more damaging to weakened trees that are over 65 years old. Here we liken this insect to the Covid-19 virus. Since the secretions of the insect are very contagious, it is not possible to approach the tree without a helmet, gloves and glasses. In fact, this situation is very similar to the mask, distance and hygiene rules in the Covid -19 Pandemic. On the other hand, trees aged 65 and over were stigmatized against the risk of contamination. Special teams were established to prevent the trees, which are at the base of the ecosystem, from being damaged, and the branches of these trees were pruned and their environment was taken under protection. The old and magnificent trees could not stand this new situation, and although they tried to hold on to life, they began to shed their leaves gradually over time. With the falling of the leaves of the

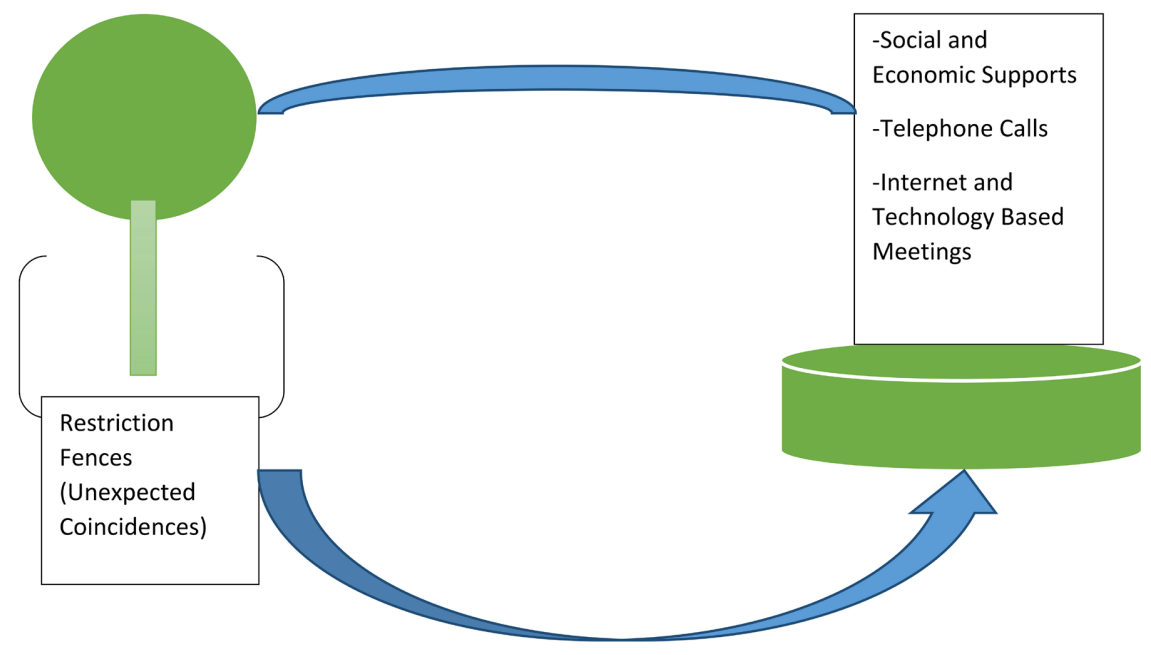

Figure 6. Solidarity. 
tree over time, the birds living in the tree also started to leave it, and other creatures could not visit it often. A solution was sought for this new situation and it was decided to help the great trees. It is known that if these trees are damaged, the entire ecosystem will collapse. Thinking that they could not live without their shadow, all other living things started to struggle with the insects that infested the roots of the trees. While transferring their nutrients to each other with their roots from underground, birds living in the branches of young trees occasionally alight on the branches of old trees to get information about their health. Here, birds are likened to tools that enable us to communicate, such as phones and smart devices. All the creatures living in the trees, on the one hand, are afraid of the insect harming them, on the other hand, they are trying to help by taking their precautions. Although progress has been made to get rid of this situation over time, the stigma of old trees has weakened them. These stigmatized trees, surrounded by fences, wanted to get rid of the constraint as soon as possible and to branch out freely as before.

\section{Conclusion}

Immediately after the virus named Covid-19 was declared as a Pandemic, various measures were taken that deeply affected daily life in line with the recommendations of the Scientific Committee established in Turkey. The 65 years and over group, which is thought to be at higher risk due to their chronic diseases, has been adversely affected by the restrictions. Reports have been published on the multidimensional negative effects of the restrictions imposed during the Covid-19 process, especially on women, children and the disabled (UN Women, 2020a: p. 2; UN, 2020b; Save the Children, 2020). In this study, it is aimed to examine the changes in their daily lives, both qualitatively and quantitatively, in relational sociological terms, based on the problem of increasing distress experienced by the elderly.

In this research, the difficulties that the ongoing restrictions in the 2020-2021 period create in the lives of retirees over the age of 65 and their interactions with these difficulties are examined. In this context, interviews were conducted with 16 individuals over the age of 65 who were members of the Ankara Turkey Retirement Association in the period of 2020-2021, and a survey was conducted with 60 people.

Studies with mixed design have recently started to be preferred. Researchers who have knowledge about both methods can choose this method to obtain comprehensive information by reducing the deficiencies of qualitative and quantitative research designs.

In the study, old age and uncertainties could be examined holistically with the opportunity provided by the theoretical framework being relational sociology. As it is known, thinkers such as Crossley (2011), Redshaw (2013), Powell and Depaltau (2013) specifically stated that relational sociology is reflexive. This point of view opposes the explanations that only the structure or system affects 
the individual. This approach also considers the individual as a social actor and as an agent who can affect structures. In this respect, the behaviors and interactions of individuals should be examined as actions that take place in a relational context. In addition, process-oriented thinking, rejection of dualities, and opposition to essentialism are at the forefront of the vital principles of relational sociology. In this article, the difficulties experienced during the restrictions imposed on people over the age of 65 during the Covid-19 period are comprehensively discussed. Considering that the phenomenon of old age is so dynamic and unique that it cannot be reduced to chronological age, it is thought that various situations should be examined multidimensionally and relationally.

According to the qualitative data of the research, retirees' concerns about the uncertainties experienced in various dimensions with Covid-19 have increased. In this context, the rapid changes in the daily lives of individuals have led to intense feelings of anxiety and fear, which are considered as "unexpected" or "contingency." In addition, as a result of the current complexity of daily life and the increase in uncertainties, individuals have tried to seek security, that is, to avoid uncertainties by developing various tactics.

According to White et al. (2013), ambage, which is called uncertainty in social relations, has been observed in retirees based on qualitative data. With the beginning of the restrictions, it was revealed that retirees mostly made phone calls in order to maintain their social relations.

In addition, H. White (1992) argues in his work titled "Identity and Control" that people avoid "uncertainty" situations that occur in their lives and try to control these uncertainties. He also emphasizes that people try to control uncertainties through "identities". In terms of identity, while the Covid-19 virus is not an epidemic in our country, it is possible for retirees to use multiple identities such as professional, friend and association member together in their social lives. With Covid-19, we can observe that the "spouse" and "grandparent" identities of the retirees within the participant come to the fore more. For example, the roles of spouses in their homes, the solidarity of spouses with each other, the parent-child relationships they establish with their children. In short, it can be said that retirees are trying to hold on to life through these two "identities". In this regard, it is possible to say, based on qualitative data, that there has been a transition from the much higher number of identities they used in different fields and subjects before Covid-19 to a dramatically decreasing number of identities with Covid-19.

Ambiguity is the uncertainty in meaning and values. We can evaluate the opinions of retirees on the meaning and duration of the restrictions imposed on the age of 65 and over during the Covid-19 epidemic, and whether this situation reduces the transmission of the virus, within the framework of "ambiguity".

In the quantitative research part of the study, it can be said that the majority of individuals neglected their regular check-ups during the Covid-19 Pandemic period, reduced their expenditures, took loans from banks, and their relations 
with relatives, friends and neighbors were significantly affected. However, when the pre- and post-Covid-19 solidarity was compared in the survey results, it was revealed that only the average of intra-family solidarity increased. The basic concept reached in the qualitative data section of the research, which was conducted in accordance with the Grounded Theory principles, was "solidarity". However, it has been understood that there are some differences in terms of "solidarity" at the point of holding on to life in various aspects. For example, it has been observed that the time spent by men for housework has increased in the period of Covid-19 for retired individuals to help their "wives".

The basic concept reached in the qualitative study section of the research, which was conducted in accordance with the Grounded Theory principles, was "solidarity". However, it has been understood that there are some differences in terms of "solidarity" at the point of holding on to life in various aspects. For example, there are differences in the way retired individuals help their "wives". Men began to devote more time to housework.

When both the survey and interview results are evaluated together, we can conclude that ensuring family unity, the loyalty of spouses to each other and being economically strong are important in healthy aging. In addition, it would not be wrong to say that internet and smartphone ownership is of critical importance in dealing with feelings of loneliness during the Covid-19 period. Because, it has been observed that people who have opportunities such as smart phones and internet diversify their time compared to individuals who do not have these opportunities, in terms of the diversity of occupations in maintaining social relations of retirees and coping with feelings of loneliness. However, it has emerged in both qualitative and quantitative data that the methods of coping with the negative emotions of retirees during the restriction process are mostly through watching television.

This situation can also show the needs of retirees such as internet, computer literacy, smart phone use, which are helpful functions in diversifying their time. In addition, we can deduce from the qualitative data that the retired individuals' walking in the parks when the restrictions are lifted has an important function in socializing. In this context, we can say that the spread of green public spaces in cities is of great importance.

\section{Conflicts of Interest}

The authors declare no conflicts of interest regarding the publication of this paper.

\section{References}

(2020a, April 9). Policy Brief: The Impact of COVID-19 on Women. United Nations. https://www.unwomen.org/sites/default/files/Headquarters/Attachments/Sections/Libr ary/Publications/2020/Policy-brief-The-impact-of-COVID-19-on-women-en.pdf

(2020b, May 6). Policy Brief: A Disability-Inclusive Response to COVID-19. United Nations. 
https://www.un.org/sites/un2.un.org/files/sg policy brief on persons with disabilitie s final.pdf

(2021, March 18). İstatistiklerle Yaşlılar, 2020. Türkiye İstatistik Kurumu (TUIK). https://data.tuik.gov.tr/Bulten/Index?p=Elderly-Statistics-2020-37227

Agamben, G. (1998). Homo Sacer: Sovereign Power and Bare Life (Trans. D. H. Roazen). Stanford University Press.

Arpacı, F., Cantekin, Ö. F., \& Yazıcıoğlu, C. T. (2021). Türkiye Emekli Profili 2. Gazi Kitabevi.

Aydın, D. H. (2021). COVID-19 Bağlamında Hukuksal Düzenlemeler ve Toplumsal Yaşamdaki Etkileri Hakkında Bir Değerlendirme. In B. Aykan, \& O. Bilginer (Eds.), Salgın Halleri: Covid-19 ve Toplumsal Eşisizlikler (pp. 115-146). Nika Yayınevi.

Aykan, B., \& Bilginer, O. (2021). Salgın Halleri: Covid-19 ve Toplumsal Eşisizlikler. Nika Yayınevi.

Beck, U. (1992). Risk Society: Towards a New Modernity(M. Ritter, Trans.). Sage.

Bramanti, D., \& Meda, S. G. (2016). Young Elderly between Activity and Fragility: Challenges and Resources Linked to Longer Life Expectations. Salute E Società, 135-153. https://www.google.com/search?q=young+elderly+between+activity+and+fragility $\% 3$ A+Challenges+and+resources+linked+to+longer+life+expectancies+Translated + title+ of+the+contribution $\% 3 \mathrm{~A}+\% 5 \mathrm{BAutom} .+$ eng.+transl.\%5D+Young+elderly

Coccia, M. (2022). Preparedness of Countries to Face Covid-19 Pandemic Crisis: Strategic Positioning and Underlying Structural Factors to Support Strategies of Prevention of Pandemic Threats. Environmental Research, 203, Article ID: 111678.

https://doi.org/10.1016/j.envres.2021.111678

Corbin, J. M., \& Strauss, A. (1990). Grounded Theory Research: Procedures, Canons, and Evaluative Criteria. Qualitative Sociology, 13, 3-21. https://doi.org/10.1007/BF00988593

Creswell, J. W. (2013). Qualitative Inquiry and Research Design: Choosing among Five Approaches (3rd ed.). SAGE Publications.

Creswell, J. W., \& Clark, V. L. P. (2011). Designing and Conducting Mixed Methods Research. Sage.

Crossley, N. (2011). Towards Relational Sociology. Routledge. https://doi.org/10.4324/9780203887066

Dannefer, D. (2003). Cumulative Advantage/Disadvantage and the Life Course: Cross-Fertilizing Age and Social Science Theory. The Journals of Gerontology. Series B, Psychological Sciences and Social Sciences, 58, S327-S337. https://doi.org/10.1093/geronb/58.6.S327

Davis, S. L. M., Esom, K., Gustav, R., Maleche, A., \& Podmore, M. (2020). A Democracy Deficit in Digital Health? Health and Human Rights Journal. https://www.hhrjournal.org/2020/01/a-democracy-deficit-in-digital-health

De Certeau, M. (1984). The Practice of Everyday Life (Vol. 1, Trans. S. F. Renadail). University of California Press.

Donati, P. (2011). Relational Sociology: A New Paradigm for the Social Sciences. Routledge.

Donati, P. (2015). Intergenerational Solidarity: Old and New Scenarios, Challenges and Prospects. In P. S. Dasgupta, V. Ramanathan, \& M. S. Sorondo (Eds.), Sustainable Humanity, Sustainable Nature: Our Responsibility (pp. 579-613). The Pontifical Academy of Sciences.

Donovan ve Blazer (2020, August 13). Social Isolation and Loneliness in Older Adults: 
Review and Commentary of a National Academies Report. The American Journal of Geriatric Psychiatry, 28, 1233-1244.

https://www.ncbi.nlm.nih.gov/pmc/articles/PMC7437541

Duben, A. (2018). Türkiye ve Avrupa'da Nüfus Yaşlanması, Aile, Piyasa Ve Devlet. In A. Duben (Ed.), Yaşlanma ve Yaşlılık: Disiplinlerarası Bakış Açıları (pp. 67-78). İstanbul Bilgi Üniversitesi Yayınları.

Edwards, J. (2020). Protect a Generation: The Impact of COVID-19 on Children's Lives. Save the Children.

https://resourcecentre.savethechildren.net/pdf/vr59-01_protect a generation report e $\underline{\mathrm{n} 0 . \mathrm{pdf}}$

Giddens, A. (1990). The Consequences of Modernity. Polity Press.

Giddens, A. (1994). Sociology (2nd ed.). Blackwell Publishers.

Glaser, B. G., \& Strauss, A. L. (1967). The Discovery of Grounded Theory: Strategies for Qualitative Research. Aldine Transaction. http://www.sxf.uevora.pt/wp-content/uploads/2013/03/Glaser 1967.pdf

Gramsci, A. (1992). Prison Notebooks (J. A. Buttigieg, Ed.). Columbia University Press.

Isik, S. B., \& Kasapoglu, A. (2021). Digital Inequality Problems of the Disabled during the Covid-19 Pandemic in Turkey. International Journal of Arts, Humanities \& Social Science, 2, 128-145.

Kasapoglu, A. (2015). ScholaAyrıntı Dizisi. Özne Hayatı Konuşunca: Sosyolojide Temellendirilmiş Kuram İncelemeleri. Ayrıntı.

Kasapoglu, A. (2019). A Road Map for Applying Relational Sociology. Advances in Social Sciences Research Journal, 6, 448-488. https://doi.org/10.14738/assri.61.5977

Kosar, A., \& Kasapoglu, A. (2021). Effects of the COVID-19 Pandemic on the Elderly: A Grounded Theory Study from Turkey. Advances in Social Sciences Research Journal, 8 , 252-266. https://doi.org/10.14738/assri.81.9613

Kurtkapan, H. (2019). Yaşlılar İçin Bir Sosyal Sermaye Kaynağı Olarak Emekli Dernekleri: İstanbul Örneği. Muhakeme Dergisi, 2, 72-82. https://doi.org/10.33817/muhakeme.567604

Lefebvre, H. (1971). Everyday Life in the Modern World (S. Rabinovitch, Trans.). Harper \& Row.

Meda, S. G., Bramanti, D., \& Rossi, G. (2017). Relational Sociological Approach to Active Ageing: The Role of Intergenerational Relations and Social Generativity. Stan Rzeczy [State of Affairs], 1, 215-239. https://doi.org/10.51196/srz.12.9

Melamed, D., \& Savage, S. V. (2013). Status, Numbers and Influence. Social Forces, 91, 1085-1104. https://doi.org/10.1093/sf/sos194

Melamed, D., Savage, S. V., \& Munn, C. (2019). Uncertainty and Social Influence. Socius: Sociological Research for a Dynamic World, 5, 1-9.

https://doi.org/10.1177/2378023119866971

Mills, C. W. (1959). The Sociological Imagination. Oxford University Press. https://doi.org/10.2307/1891592

Moscovici, S., Lage, E., \& Naffrechoux, M. (1969). Influence of a Consistent Minority on the Responses of a Majority in a Color Perception Task. Sociometry, 32, 365-380. https://doi.org/10.2307/2786541

Özen, İ. C. (2021). Farklı Çağların, Ekonomilerin ve Coğrafyaların Vebaları: COVID-19 ve HIV/AIDS. In B. Aykan, \& O. Bilginer (Eds.), Salgın Halleri: Covid-19 ve Toplumsal Eşisizlikler (pp. 173-220). Nika Yayınevi. 
Özsungur, F. (2018). Yaşlıların Teknoloji Kabul ve Kullanım Davranışlarının Başarılı Yaşlanma Üzerindeki Etkilerinin Analizi: Adana İli Örneği (531791). PhD, Hacettepe Üniversitesi. http://www.openaccess.hacettepe.edu.tr/

Pfeffer, J., Salancik, G. R., \& Leblebici, H. (1976). The Effect of Uncertainty on the Use of Social Influence in Organizational Decision Making. Administrative Science Quarterly, 21, 227-245. https://doi.org/10.2307/2392044

Powell, C., \& Dépelteau, F. (Eds.). (2013). Conceptualizing Relational Sociology: Ontological and Theoretical Issues. Palgrave Macmillan US. https://doi.org/10.1057/9781137342652

Redshaw, S. (2013). Feminist Preludes to Relational Sociology. In C. Powell, \& F. Dépelteau (Eds.), Conceptualizing Relational Sociology: Ontological and Theoretical Issues (pp. 13-26). Palgrave Macmillan US. https://doi.org/10.1057/9781137342652 2

Rossi, G., Boccacin, L., Bramanti, D., \& Meda, S. G. (2014). Active Ageing: Intergenerational Relationships and Social Generativity. Studies in Health Technology and Informatics, 203, 57-68.

Şentürk, Ü. (2021). Bir Dezavantajlı Grup Olarak Yaşlıların Pandemi Halleri: "Kapatılma" ve "Damga". In E. Başaran, \& R. C. Alkın (Eds.), Pandemi Sürecinde Dezavantajlı Gruplar (pp. 35-64). Necmettin Erbakan Üniversitesi Yayınları.

Strauss, A. L., \& Corbin, J. M. (1990). Basics of Qualitative Research: Grounded Theory Procedures and Techniques (2nd ed.). SAGE Publications.

TPL (2020). Special Report: Parks and the Pandemic. The Trust for Public Land. https://www.tpl.org/sites/default/files/Parks\%20and\%20Pandemic\%20-\%20TPL\%20spe cial\%20report.pdf

Tuna, M. (2012). Çevre Sosyolojisi. Anadolu University.

Tuna, M. (2021). Pandeminin Sosyolojisi. Sosyoloji Araştırmaları Dergisi, 24, 320-348. https://doi.org/10.18490/sosars.927260

Tushman, M. L., \& Romanelli, E. (1983). Uncertainty, Social Location and Influence in Decision Making: A Sociometric Analysis. Management Science, 29, 12-23. https://doi.org/10.1287/mnsc.29.1.12

White, H. C. (1992). Identity and Control: A Structural Theory of Social Action. Princeton University Press.

White, H. C., Godart, F. C., \& Thiemann, M. (2013). Turning Points and the Space of Possibles: A Relational Perspective on the Different Forms of Uncertainty. In F. Dépelteau, \& C. Powell (Eds.), Applying Relational Sociology: Relations, Networks, and Society (pp. 137-154). Palgrave Macmillan US. https://doi.org/10.1057/9781137407009 6

Xie, J., Luo, S., Furuya, K., \& Sun, D. (2020). Urban Parks as Green Buffers during the COVID-19 Pandemic. Sustainability, 12, 6751. https://doi.org/10.3390/su12176751 